\title{
RMetS
}

Royal Meteorological Society

\section{Radar climatology of the COPS region}

\author{
Tammy M. Weckwerth, ${ }^{\text {a }}$ James W. Wilson, ${ }^{\mathrm{a}}$ Martin Hagen, ${ }^{\mathrm{b}}$ Tracy J. Emerson, ${ }^{\mathrm{a}}$ \\ James O. Pinto, ${ }^{\mathrm{a}}$ Daran L. Rife ${ }^{\mathrm{a}}$ and Leslie Grebe ${ }^{\mathrm{b}}$ \\ ${ }^{a}$ National Center for Atmospheric Research, Boulder, Colorado, USA \\ ${ }^{\mathrm{b}}$ Deutsches Zentrum für Luft- und Raumfahrt, Institut für Physik der Atmosphäre, Oberpfaffenhofen, Germany \\ ${ }^{*}$ Correspondence to: Tammy M. Weckwerth, NCAR, 3450 Mitchell Lane, Boulder, CO 80301, USA. \\ E-mail: tammy@ucar.edu
}

A climatology of convection initiation (CI) and convective enhancements (CE) has been developed using radar reflectivity data in southwestern Germany and eastern France over the period of May-August of 2000-2006 and 2008. The study region included the Vosges Mountains of France, the Rhine Valley which straddles France and Germany, the Black Forest Mountains and the Swabian Mountains of Germany. Convection occurred frequently during the summer months throughout the study region. The CI density (number of initiations per square $\mathrm{km}$ ) illustrates preferential formation in the mountain regions while the $\mathrm{CE}$ events spanned both mountains and valleys nearly equally. There is a strong mid-day peak of the $\mathrm{CI}$ events suggesting that diurnal heating is critical for $\mathrm{CI}$ in the region. The very strong thunderstorms ( $>46 \mathrm{dBZ}$ ) first occurred in the mountains and $\sim 2 \mathrm{~h}$ later in the Rhine Valley.

During the summer of 2007, the Convective and Orographically-induced Precipitation Study (COPS) field campaign was conducted with the objective of obtaining improved understanding of convective processes and short-term quantitative precipitation forecasting in low-mountain regions. Comparisons were made between the radar climatology results and the COPS summer. The COPS summer exhibited preferential CI density in the mountainous regions but not as pronounced as the climatology. The COPS summer had a similar diurnal peak of CI events as climatology but the ratio of daytime to nighttime CI (1.7), or amplitude of the diurnal cycle, was less than that of climatology (3.0). While both the 8-year climatology and COPS summer were dominated by daytime, locally-forced CI occurrences, the broad distribution of daytime $\mathrm{CI}$ events and increase in nighttime events observed during COPS indicate a more active synoptic pattern in 2007. Copyright (c) 2011 Royal Meteorological Society

\footnotetext{
Key Words: convection initiation; convective enhancements; orographic thunderstorms

Received 15 February 2010; Revised 17 October 2010; Accepted 22 November 2010; Published online in Wiley Online Library 4 February 2011

Citation: Weckwerth TM, Wilson JW, Hagen M, Emerson TJ, Pinto JO, Rife DL, Grebe L. 2011. Radar climatology of the COPS region. Q. J. R. Meteorol. Soc. 137: 31-41. DOI:10.1002/qj.747
}

\section{Introduction}

Quantitative precipitation forecasting (QPF) skill affects society in terms of flash floods, agriculture, transportation and severe storm prediction. One path toward improved QPF skill is a better understanding of convection initiation (CI) and evolution processes. In the presence of instability,
CI has been attributed to boundary-layer convergence zones (e.g. Wilson and Schreiber, 1986), orographic impacts (e.g. Banta and Schaaf, 1987) and synoptic-scale forcing mechanisms (e.g. Mercer and Richman, 2007). This paper aims to develop a radar climatology of CI and convective enhancement (CE) events in the low-mountain regions of southwestern Germany and eastern France. The region 
encompassed the Convective and Orographically-induced Precipitation Study (COPS) domain. The COPS field campaign was undertaken to better understand convective processes and QPF in low-mountain regions (Wulfmeyer et al., 2008).

Previous research on CI in complex terrain has shown that convection preferentially develops in the mountains (e.g. Banta and Schaaf, 1987; Tucker and Crook, 2005; Aoshima et al., 2008). Banta and Schaaf (1987) used visible and infrared satellite imagery, along with wind observations from rawinsondes and surface observations, to study CI in the US Rocky Mountains during the period of July-August from 1983 to 1984 . They found that several mechanisms led to CI in preferred regions of the mountains: (i) orographic lifting, (ii) leeside convergence, (iii) channeling and (iv) wake effects.

Some climatological thunderstorm studies have been performed in southern Germany. Höller (1994) used radar data during May-August from 1987 to 1992 to show that $29 \%$ of the days had thunderstorms. Furthermore hailstorms were frequently observed $(61 \%$ of the thunderstorm days). Three years (1992-1994) of lightning statistics were evaluated by Finke and Hauf (1996). They noted that thunderstorms with lightning typically approached from the southwest or west and had lifetimes greater than four hours. Most of those thunderstorms occurred in May-August at 1600-1700 UTC. (All times are UTC; Daylight Saving Time (DST) $=$ UTC $+2 \mathrm{hr}$; Local Solar Time (LST) $=$ UTC $+30 \mathrm{~min})$. The greatest frequency of lightning occurrences were on the leeward side of the Black Forest Mountains. Hagen et al. (1999) performed a fiveyear (May-September, 1992-1996) lightning climatology in southern Germany in a region that was slightly east of the study area in this paper. While not sampling CI, they found that mature thunderstorms with lightning occurred on $53 \%$ of the summertime days. Stationary and moving thunderstorms, respectively, occurred on $56 \%$ and $44 \%$ of the days. Grebe (2009) performed a nine-year (2000-2008) summertime climatological radar and lightning study in the COPS region, similarly looking at only strong convection ( $>46 \mathrm{dBZ}$ ), and found that most thunderstorms occurred under southwesterly flow regimes and occurred in the mountains. Furthermore the average convective available potential energy (CAPE) and convective inhibition (CIN) values over the period were quite modest $\left(233 \mathrm{~J} \mathrm{~kg}^{-1}\right.$ and $44 \mathrm{~J} \mathrm{~kg}^{-1}$, respectively). While each of these studies contribute to the knowledge of thunderstorms in the southern Germany region, none of these climatological studies examined CI.

A small number of relevant CI studies have been performed in the COPS region. Aoshima et al. (2008) performed a Meteosat rapid scan high-resolution CI satellite climatology during the COPS Intensive Operation Periods (IOPs) of June-August 2007. They found that the CI density (CI events per area) was three times greater in the Vosges and Black Forest mountains than in the Rhine Valley. There was a pronounced maximum (18\% of all CI events) at 1300-1400 UTC, suggesting that the convection was driven by the daytime heating of the planetary boundary layer. Case-studies showed that a combination of diurnal heating and mesoscale convergence zones led to CI despite limited thermodynamic support (i.e. low CAPE and relatively high CIN; Kalthoff et al., 2009). Hagen et al. (2011) compared two CI days during COPS and noted that the Rhine Valley is densely populated with strong industrial activity; therefore they suggested that the heat island effect could supply enough buoyancy to overcome the CIN and allow for thunderstorm development.

This article presents results of a radar data climatology in southwestern Germany and eastern France to determine the locations and timing of CI and CE events during May-August of 2000-2006 and 2008. The COPS summer of 2007 was analysed but was excluded from the radar climatology statistics to allow for comparisons between COPS and climatology. The study region encompassed the COPS domain and included the Vosges Mountains of France, the Rhine Valley which straddles France and Germany, the Black Forest Mountains and the Swabian Mountains of Germany. The data and methodology are described in section 2. Results are shown in section 3 and the conclusions are presented in section 4 .

\section{Data and methodology}

The dataset used for these radar analyses was the German Weather Service (Deutscher Wetterdienst, DWD) C-band radar reflectivity composite with $4 \times 4 \mathrm{~km}$ spatial and $15 \mathrm{~min}$ temporal resolution during May-August of 2000-2008. Data from the COPS summer, 2007, are not included in the climatological plots because they are shown separately for comparison. The DWD created a European radar reflectivity mosaic and archived their column-maximum reflectivity data into six intensity bins: very light (7-18.5 dBZ), light (19-27.5 dBZ), moderate (28-36.5 dBZ), strong (37-45.5 $\mathrm{dBZ}$ ), very strong (46-54.5 dBZ), and extreme (>55 dBZ). A subset of these European radar data were used for this climatology to focus on the COPS domain, including the Vosges Mountains, the Rhine Valley, the Black Forest Mountains and the Swabian Mountains (Figure 1). The study area encompassed $>25000 \mathrm{~km}^{2}$ with $52 \%$ (48\%) of the area covering mountainous (Rhine Valley) regions. For this study, the three mountain ranges and the Rhine Valley were divided into north and south sections (thin white lines in Figure 1) to assess the variations in CI and CE between the different regions.

During the summers of 2005-2006, the DWD mosaic radar data was missing approximately half of the time, therefore the MeteoSwiss C-band radar composite dataset $(2 \times 2 \mathrm{~km} / 5 \mathrm{~min}$ spatial/temporal resolution) was used to fill in the temporal gaps for those two summers. Comparisons between the two datasets when the DWD data were available show good correspondence except in the Vosges Mountains since the MeteoSwiss radars were quite far away and suffered from significant low-level blockage. Therefore the MeteoSwiss radars could not be used to identify early CI events in the Vosges Mountains until the storms were deep and relatively well-developed. Additionally the MeteoSwiss radars may have suffered from attenuation due to intervening storms. It is therefore possible that the estimates of CI, and perhaps CE, in the Vosges Mountains and in the northern sections of the domain farther away from the MeteoSwiss radars, are lower than actually occurred. The results from 2005-2006, however, do not exhibit a clear bias (not shown).

Convection initiation was defined when a radar image illustrated new convection with radar reflectivities at or above the moderate threshold (defined as $28-36.5 \mathrm{dBZ}$ ). This reflectivity interval was chosen as the threshold based 


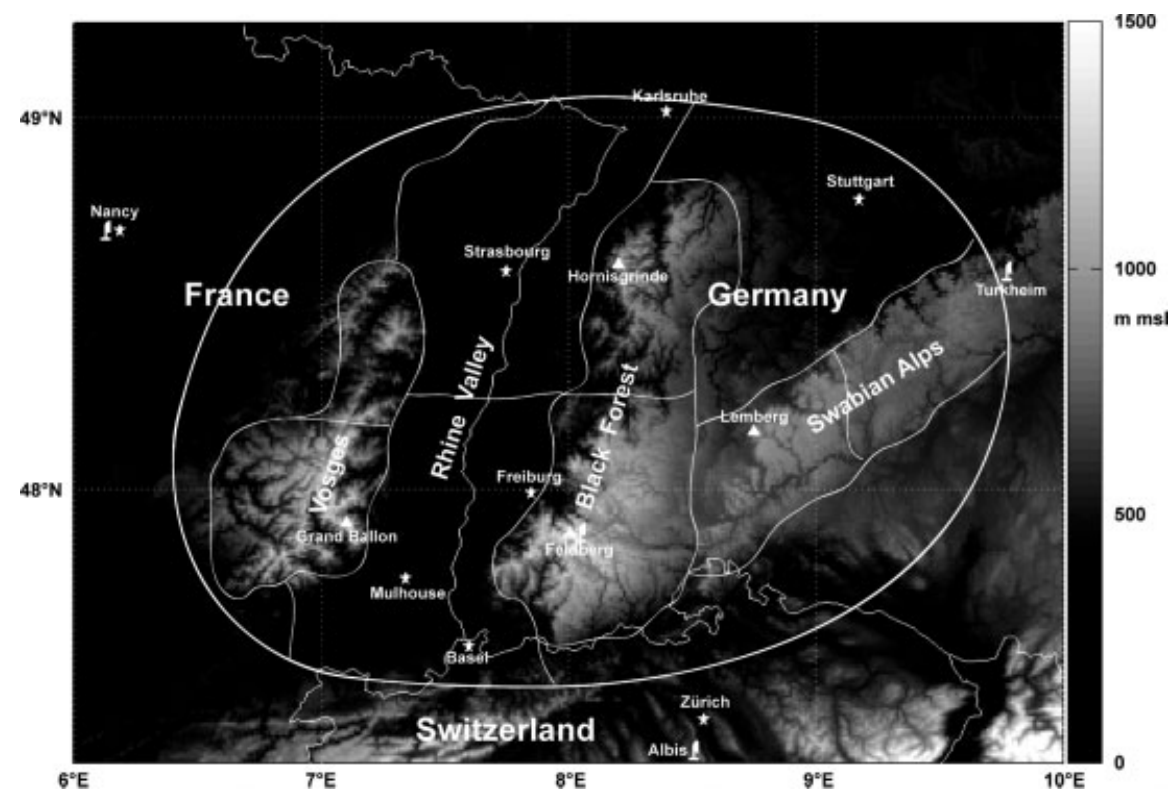

Figure 1. Map of southwestern Germany/eastern France showing the COPS domain used in this radar climatology study (white near-circular boundary). Elevation (shading) is shown in $\mathrm{m}$ above mean sea level (msl). Radar locations used in this study are shown by the radar symbols. Mountain peaks for the three COPS mountain ranges are shown as triangles. Thin lines separate the different regions used in this study which are listed in Table I and shown in Figures 8 and 10.

on previous work defining CI when radar reflectivity values exceeded 35 dBZ (e.g. Wilson and Schreiber, 1986; Mecikalski and Bedka, 2006) since that value correlates well with the development of mature cumulonimbus clouds (Roberts and Rutledge, 2003). If there was adjacent existing convection, identification of CI was not made. The rules for identifying CI events in this study were: (i) observing a new radar echo with reflectivity at or above the moderate threshold (28-36.5 dBZ), (ii) the echo must encompass at least two adjacent pixels (storm size greater than $32 \mathrm{~km}^{2}$ ), (iii) the echo must have a lifetime of at least $15 \mathrm{~min}$ and (iv) it must show intensity and/or size variation with time to ensure that it was meteorological echo rather than ground clutter or anomalous propagation. A potential bias in these analyses occurs with merged storms. When multiple $\mathrm{CI}$ events produce storms that later merge, they will bias the results pertaining to duration, intensity and areal coverage. Thus multiple initial storms would be tagged with the same duration, intensity and areal coverage results. The merged storms account for the majority of the large and long-lived events, as will be discussed in section 3.3.

Thunderstorm days were classified within the COPS region when lightning was detected and radar reflectivities exceeded $46 \mathrm{dBZ}$. The thunderstorms included all storms that initiated and grew within the COPS domain, as well as those that advected into the region. The shape, size and duration of the radar echoes were used to further classify the thunderstorm days as: (i) relatively short-lived, small, isolated single cells, (ii) thunderstorms associated with fronts defined on synoptic charts, and (iii) mesoscale convective systems (MCSs), including multicellular structures, supercells and squall lines. If more than one convective type occurred on any day, then the day was categorized with the type that spanned the largest area of the domain.

Figure 2 shows an example of several CI events on 25 July 2000. Ground clutter is visible in Figure 2(a) but no storm echoes are observed at 0945 UTC. By 1000 UTC (Figure 2(b)) CI, labelled cell A, is identified in the central
Rhine Valley. Cell A grew and intensified by 1015 UTC (Figure 2(c)) and 1030 UTC (Figure 2(d)). Note that there was a CI event south of the study area; events outside the study area were not counted for this analysis. New cells formed in the Swabian Mountains, labelled B and C, at 1115 UTC while cell A continued its growth as it propagated into the northern Black Forest Mountains (Figure 2(e)). By 1130 UTC another cell, labelled D, had formed near Stuttgart (Figure 2(f)). The maximum eventual storm size, intensity and duration of all the $\mathrm{CI}$ events were recorded. The size was based upon size relative to the Vosges Mountains. Storms classified as small storms never grew larger than the size of the southern Vosges $\left(\sim<2000 \mathrm{~km}^{2}\right)$. Medium-sized storms were $\sim 2000-3500 \mathrm{~km}^{2}$, large storms were greater than the size of the entire Vosges Mountains $\left(\sim>3500 \mathrm{~km}^{2}\right)$.

When any type or category of pre-existing radar echoes propagated into the study region and intensified by at least one reflectivity category, a CE event was identified. Figure 3 shows an example of three CE events. On 17 July 2007 at 2230 UTC some regions of moderate to strong reflectivity advected into the study region (Figure 3(a)). By 0030 on 18 July 2007 approximately half of the study region was covered with radar echo (Figure $3(\mathrm{~b})$ ). At 0100 UTC enhancement A was identified in the southern Rhine Valley (Figure 3(c)). The very strong convection continued as the system propagated northeastward by 0130 UTC (Figure 3(d)). Two other enhancements developed at 0200 UTC (Figure 3(e)), labelled B and C, respectively, in the eastern Rhine Valley and the northern Black Forest. Enhancement A continued and enhancements B and C merged together as they all propagated northeastward at 0230 UTC (Figure 3(f)).

For all of the $3190 \mathrm{CI}$ and all of the $1327 \mathrm{CE}$ events throughout the nine summers, the centroid location, elevation, time of day, maximum intensity achieved and maximum areal coverage were recorded. The compilation of CI, CE and thunderstorm events and analyses of their timing and distribution will be presented. 


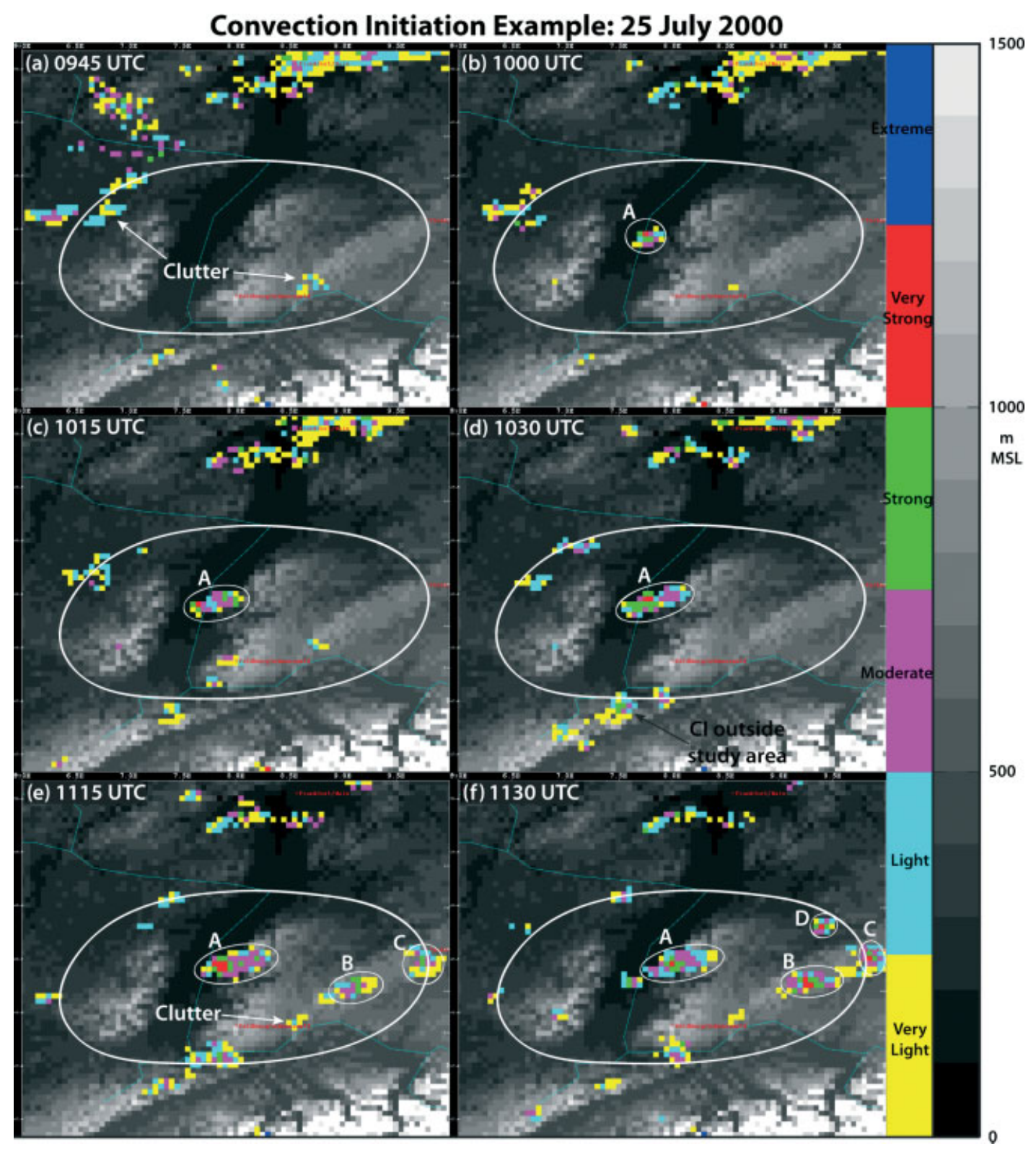

Figure 2. Example of convection initiation events on 25 July 2000. (a) 0945 UTC with no convection in the COPS domain. The scattered coloured regions are ground clutter. (b) 1000 UTC showing CI (labelled A) in the central Rhine Valley, (c) 1015 UTC and (d) 1030 UTC, both showing further development of cell A (note there is CI outside the COPS study area), (e) 1115 UTC showing two more CI events, labelled B and C, and (f) 1130 UTC additionally showing new cell D.

\section{CI and CE climatology}

\subsection{Dates of occurrences}

The radar climatology of the COPS region showed that $71.6 \%$ of the days had some form of convective precipitation. Figure 4 shows the number of CI days and the number of thunderstorm days separated into different convective organization categories. The CI events include all convective cells while the thunderstorms occurrences are defined when lightning was detected within strong convection with reflectivities $>46 \mathrm{dBZ}$. The number of $\mathrm{CI}$ and thunderstorm days track each other and were variable from year to year. The COPS summer, 2007, had the most CI days and the most thunderstorm days in this period but the majority of the COPS thunderstorms were synoptically driven (categories of frontal thunderstorms and supercells and many MCSs), rather than locally forced. This more frequent influence of synoptic forcing in generating storms is suggested in further results in this article and was also noted in Wulfmeyer et al. (2011).

The seasonal data are presented in $1 \mathrm{~d}$ bins, which is the temporal resolution of the data (Figure 5). This bin interval is consistent with the e-folding length of $1 \mathrm{~d}$, as determined from the autocorrelation statistics. CI events were identified on $61.8 \%$ of the summertime days in the nine-year period. The climatology indicates that CI is equally likely to occur on any given day throughout the summers of 2000-2006 and 2008 (grey bars of Figure 5(a)). There were $42.4 \%$ of the days that had $\mathrm{CE}$ of existing systems propagating through the COPS region. Similarly, the percentage of climatological CE events was also quite uniform throughout the summer (Figure 5(b) grey bars). During May-August of 2007, the COPS summer, $82.9 \%$ of the days had some form of convective precipitation with reflectivity values $>28 \mathrm{dBZ}$. 


\section{Convective Enhancement Example: 18 July 2007}

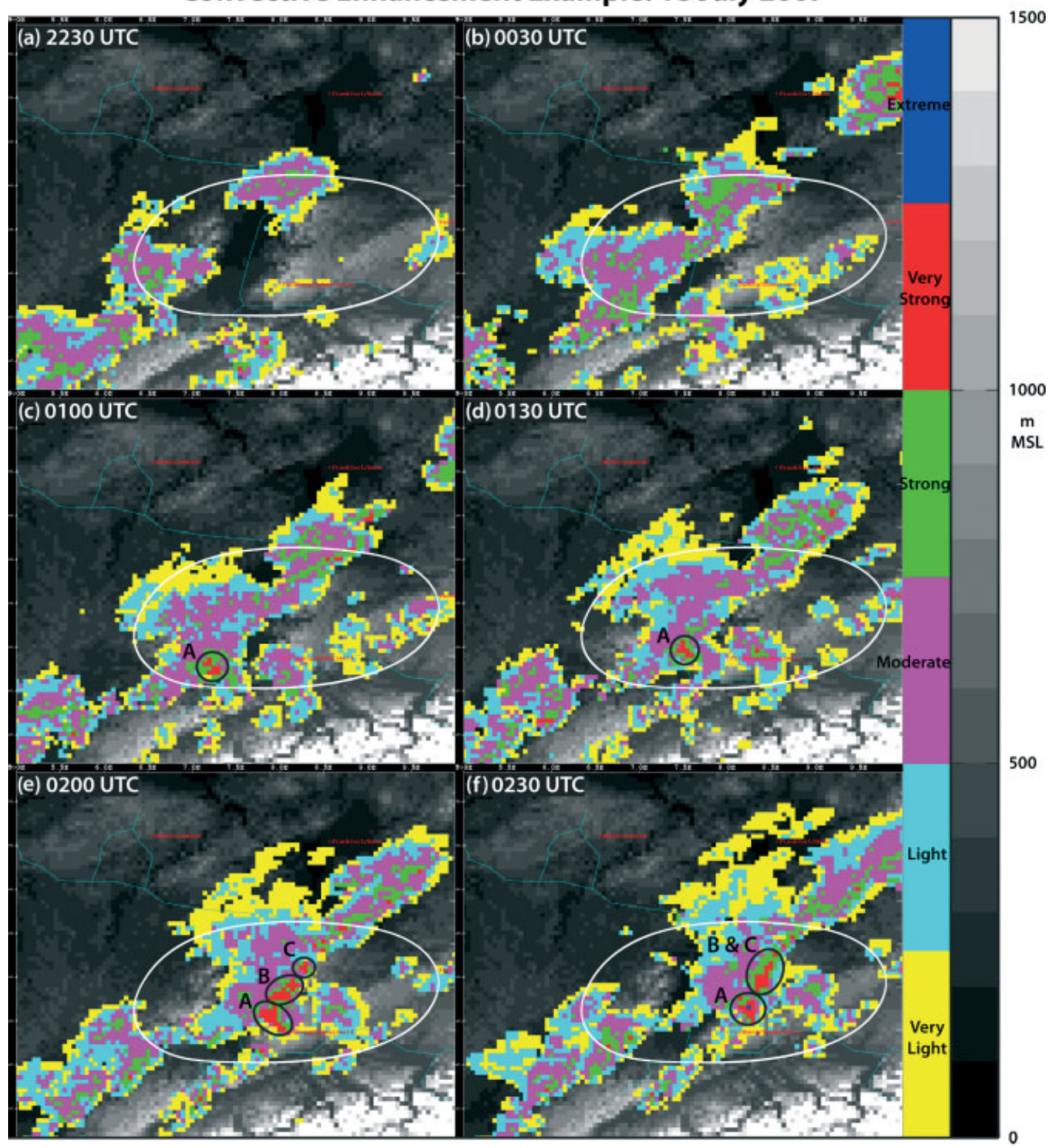

Figure 3. Example of convective enhancement events on 17-18 July 2007. (a) 2230 UTC on 17 July 2007 showing moderate/strong convective systems moving into the COPS region, (b) 0030 UTC on 18 July 2007 illustrating moderate/strong convection covering half of study region, (c) 0100 UTC illustrating convective enhancement A in the southern Rhine Valley, (d) 0130 UTC and (e) 0200 UTC with convective enhancements B and C in the eastern Rhine Valley and northern Black Forest, respectively, and (f) 0230 UTC showing merging of enhancements B and C.

CI and CE events, respectively, occurred on $70.7 \%$ and $52.0 \%$ of the summertime COPS days.

While the percentages of COPS CI and CE days were similar to climatology, the character, timing and distribution of the convection appear to be somewhat different. The nonparametric Wilcoxon-Mann-Whitney statistical test was used to assess the significance of the differences between the climatological distribution of $\mathrm{CI}$ and $\mathrm{CE}$ and that observed during the COPS summer (e.g. Yue and Wang, 2002; Rife et al., 2009). The time series for both the 8-year climatology and the 2007 season were whitened in order to remove the effects of serial correlation that might lead to unwarranted rejection of the null hypothesis of the Wilcoxon-Mann-Whitney test (Wilks, 2006). The whitening was done following the procedure outlined in Yue and Wang (2002) whereby the lag-1 autocorrelation was removed from each series using a first-order autoregression model. Rather than the climatological pattern of illustrating
CI events on most days, the COPS summer exhibited a higher percentage of CI events on fewer days. The nonparametric Wilcoxon-Mann-Whitney test resulted in a 99.4\% confidence level that the climatology and COPS time series shown in Figure 5(a) are unique. COPS had a greater incidence of CI events from late May to mid-June than shown in the climatology. This period was punctuated by several very active days with the top five days accounting for over $15 \%$ of the summer's CI events. The second half of the COP summer was relatively quiescent, with $66 \%$ of the days having fewer $\mathrm{CI}$ events than the expected climatology.

Similarly the non-parametric Wilcoxon-Mann-Whitney test showed that the climatological CE and COPS CE distributions of Figure 5(b) were distinct with a confidence of $99.0 \%$. Enhancement events in the COPS summer of 2007 showed a higher percentage of CE events in early May, midJune and early July (black bars of Figure 5(b)). Similar to CI events, the frequency of occurrence of CE events was much 


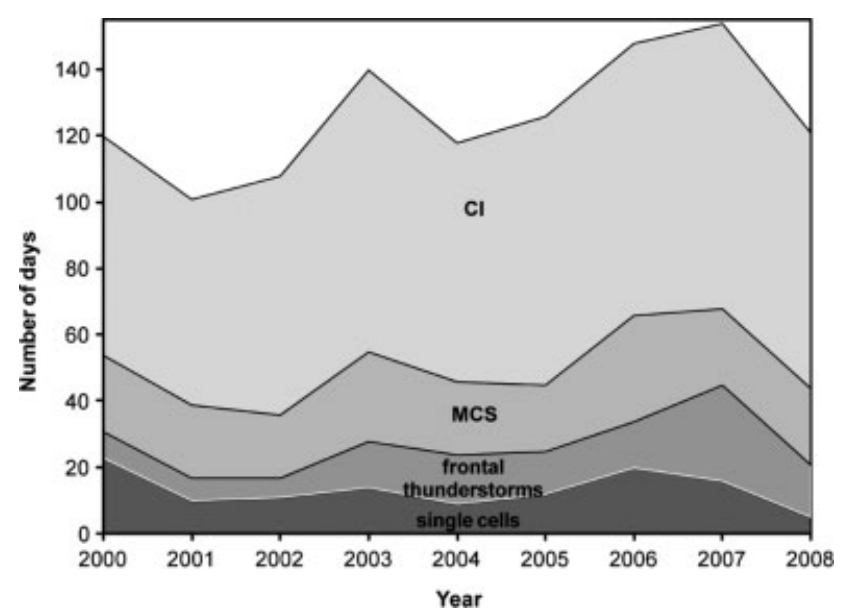

Figure 4. Number of convection initiation and thunderstorm (radar reflectivities $>46 \mathrm{dBZ}$ ) days per year. Categories of thunderstorm days were defined as short-lived single cellular, frontal convection and mesoscale convective systems (including multi-cells, supercells and squall lines).
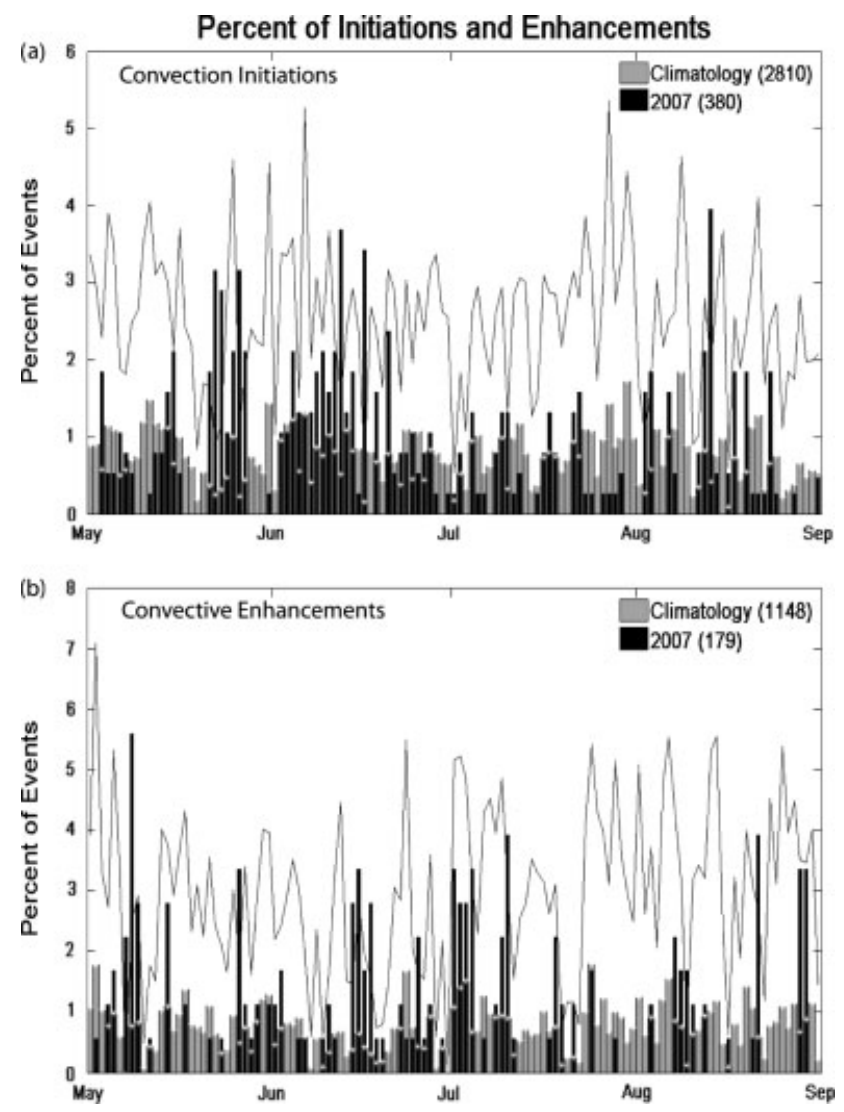

Figure 5. Percent of (a) CI and (b) CE events within the COPS region versus date for 2000-2006 and 2008 (grey) and COPS summer of 2007 (black). Each vertical bar corresponds to one day. Climatological means are shown by white stars and the grey line marks the high side of the $95 \%$ confidence interval.

less than the climatology, particularly in mid-July-August. Overall, the COPS convection, both in terms of CI and CE, occurred on fewer days than the climatology, particularly after early July.

\subsection{Spatial distribution of events}

From previous research of CI in complex terrain, it was expected that there would be an obvious increase in

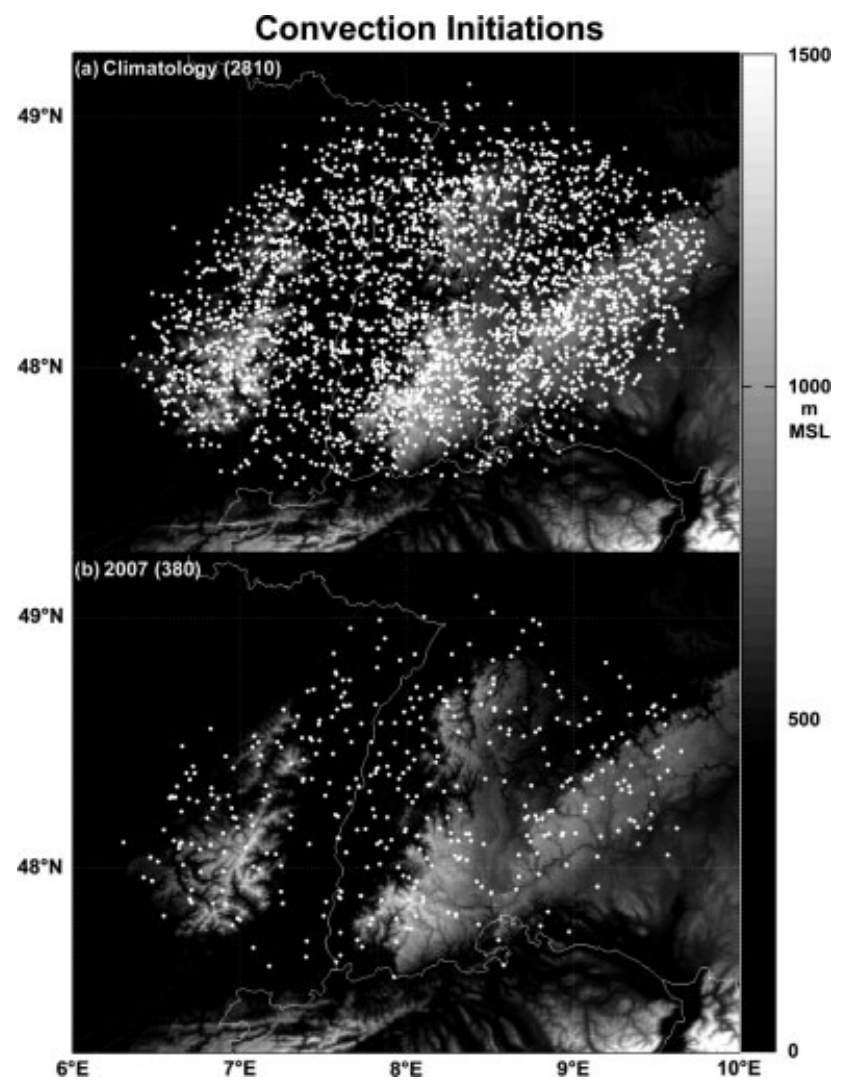

Figure 6. Convection initiation locations within the COPS domain for summer months of (a) 2000-2006 and 2008 and (b) 2007. The number of $\mathrm{CI}$ events for each time period is shown in parentheses.

occurrence of CI events near the mountain peaks (e.g. Banta and Schaaf, 1987). Figure 6 shows the location of CI events for the climatological period 2000-2006 and 2008 (Figure 6(a)), and for 2007 alone, the COPS summer (Figure 6(b)). CI locations are distributed throughout the entire study area, with an apparent slight increase in density over the southern Vosges Mountains, southern Black Forest and in the western Swabian Mountains (Figure 6(a)). There are minor variations in the year-by-year maps, but widespread occurrences of CI events are observed every summer, including the COPS summer (Figure 6(b)).

While the CI climatology shows some preference for higher terrain, the CE events show no clear relationship with the underlying mountains (Figure $7(\mathrm{a})$ ). This is also true for the COPS summer of 2007 (Figure 7(b)). Convective enhancement events occur throughout the domain with no obvious increase in density in any of the regions.

In order to quantify whether there are preferred locations for CI and CE, the number of events per area for each region was calculated. For the different regions illustrated in Figure 1, the annual-average densities (events per $1000 \mathrm{~km}^{2} \mathrm{y}^{-1}$ ) of CI and CE events for both the eightyear climatology period and for 2007 alone are shown (Figure 8 and Table I). During the entire climatological period, the mountain regions (average of $13.5 \mathrm{CI}$ events per $1000 \mathrm{~km}^{2} \mathrm{y}^{-1}$ ) had the highest density of initiations while the Rhine Valley produced approximately one-half as many CI events (average of 6.9 CI events per $1000 \mathrm{~km}^{2} \mathrm{~km}^{2} \mathrm{y}^{-1}$ ). Table I shows that the greatest density of CI events occurred in the western Swabian Mountains (16.0 CI events per $1000 \mathrm{~km}^{2} \mathrm{y}^{-1}$ ) and the southern Black Forest Mountains (14.6 CI events per $1000 \mathrm{~km}^{2} \mathrm{y}^{-1}$ ). In contrast, the southern 


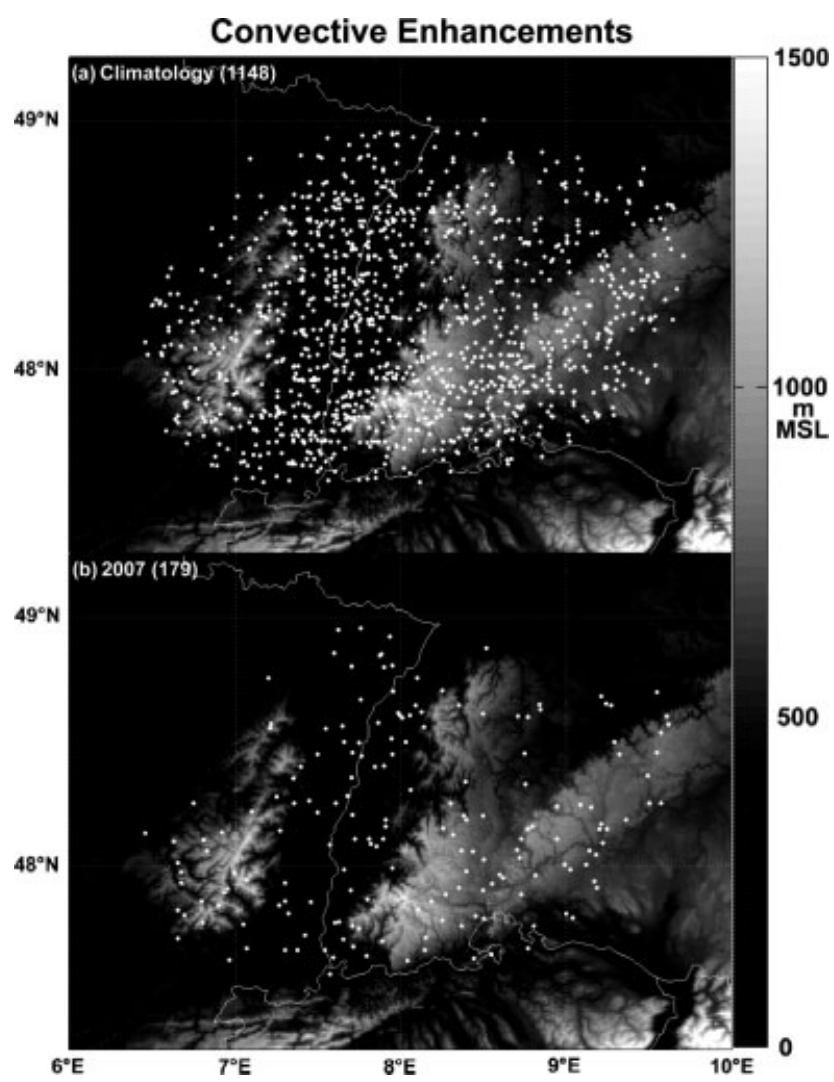

Figure 7. Convective enhancement locations in COPS domain for summer months of (a) 2000-2006 and 2008 and (b) 2007. Number of CE events are shown in parentheses.

Rhine Valley had only 7.4 CI events per $1000 \mathrm{~km}^{2} \mathrm{y}^{-1}$. This preference for mountain CI suggests that orographic lifting and convergence associated with diurnal heating and upslope flows play an important role in CI in the COPS region.

In 2007 alone, the maximum density of CI events, as shown in the parentheses of Table I, occurred in the northern Vosges and eastern Swabian Mountains (13.8 CI events per $1000 \mathrm{~km}^{2}$ ). The average CI density of the mountain regions was $13.2 \mathrm{CI}$ events per $1000 \mathrm{~km}^{2}$, while the average CI density in the Rhine Valley was $8.6 \mathrm{CI}$ events per $1000 \mathrm{~km}^{2}$. The ratio of mountain to valley CI was less in the COPS summer (1.5) than in the climatological data (2.0), further suggesting that different forcing mechanisms were dominant in 2007 than in the 2000-2006/2008 climatology.

Table I additionally shows densities of the CI events of various regions separated into different categories for maximum strength and size attained, duration of the storm and time of CI. Several differences are found between storms that initiate in the mountains and those that initiate over the valley. For example, the average density of CI events that developed into intense storms $>55 \mathrm{dBZ}$ in the mountains was $3.3 \mathrm{CI}$ events per $1000 \mathrm{~km}^{2} \mathrm{y}^{-1}$ compared with only 1.1 CI events per $1000 \mathrm{~km}^{2} \mathrm{y}^{-1}$ in the Rhine Valley (Table I). Similarly, the largest (larger than the size of the Vosges Mountains) and longest duration ( $>3 \mathrm{~h}$ ) storms had higher average densities in the mountains (2.8 and $7.5 \mathrm{CI}$ events per $1000 \mathrm{~km}^{2} \mathrm{y}^{-1}$, respectively) that were $\sim 2.5$ times greater than the average densities of CI events in the Rhine Valley (1.1 and $3.1 \mathrm{CI}$ events per $1000 \mathrm{~km}^{2} \mathrm{y}^{-1}$, respectively). These large and long-lived storms were often formed by cell mergers. In particular, merged storms caused $91 \%$ of
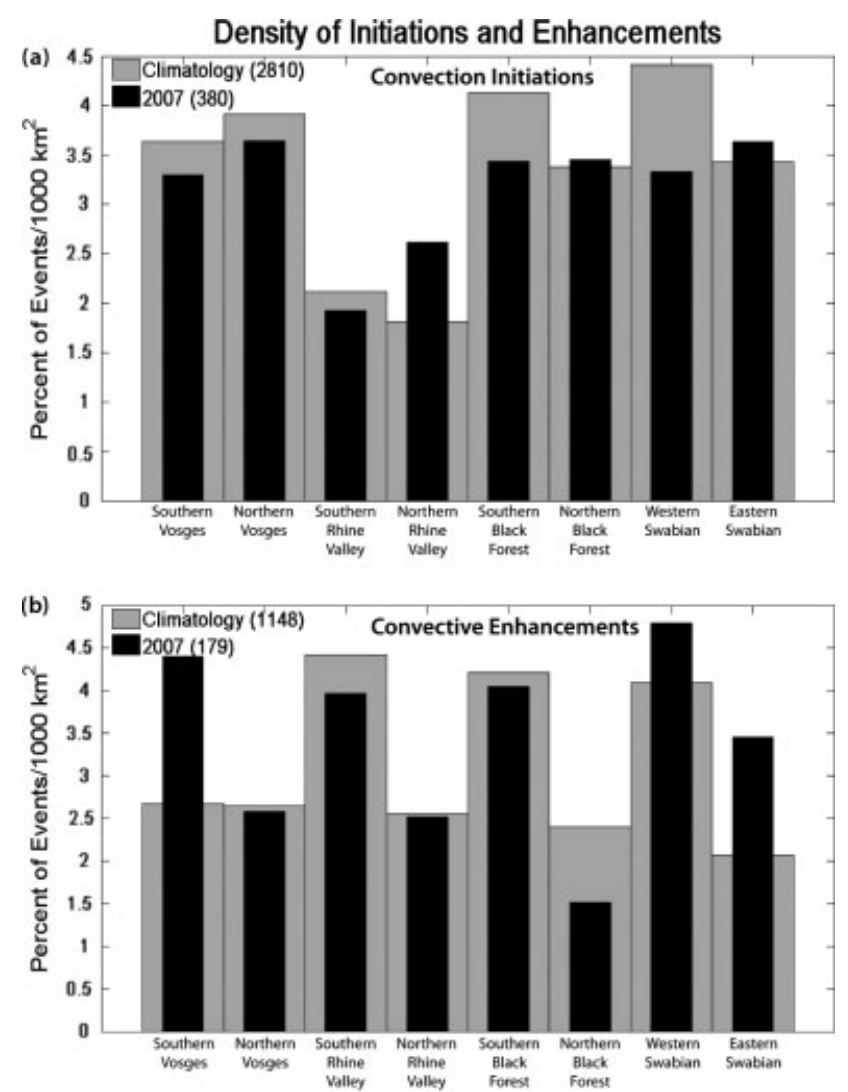

Figure 8. Histogram of summertime (a) CI and (b) CE densities (percent of occurrences per area per year) for the 2000-2006 and 2008 climatology (grey bars) and 2007 (black bars) for each of the regions shown in Figure 1.

the large storms and $62 \%$ of the long-lived storms. For the weaker, smaller and short-lived storms, there was 50\% greater occurrence of CI events in the mountains than in the valley. For example, the storms that reached only $36 \mathrm{dBZ}$ had a highest density occurrence in the western Swabian Mountains (1.8 CI events per $1000 \mathrm{~km}^{2} \mathrm{y}^{-1}$ ) while the density at this reflectivity threshold in the southern Rhine Valley was $0.9 \mathrm{CI}$ events per $1000 \mathrm{~km}^{2} \mathrm{y}^{-1}$. Similar results were obtained during the COPS summer (density values shown in parentheses in Table I). Thus the stronger, larger and long-lived storms had a 2 to 3 times greater density occurrence in the mountains than in the Rhine Valley. The weaker, smaller and short-lived storms were more evenly distributed between the mountains and the Rhine Valley but still preferentially occurred in the mountains with a mountain to valley ratio of 1.5 .

The CE densities were more uniformly distributed across the mountains and Rhine Valley. This is shown in Figure 8(b) and in the densities of CE events shown in Table I. In fact, the average density of CE events across all of the COPS mountains ( 4.6 enhancements per $1000 \mathrm{~km}^{2} \mathrm{y}^{-1}$ ) was slightly less than the density in the Rhine Valley (average of 5.1 enhancements per $1000 \mathrm{~km}^{2} \mathrm{y}^{-1}$ ). One possible explanation for the high density of $\mathrm{CE}$ events in the valley may be that moisture accumulates in the valley and provides additional conditional instability for convective systems propagating through the region. This hypothesis is consistent with soil moisture enhancements observed in the Rhine Valley (Kalthoff et al., 2011). The results were similar in 2007: the average CE density of the mountain regions was 6.3 enhancement events per $1000 \mathrm{~km}^{2}$, while the average CE 
density in the Rhine Valley was 5.8 enhancement events per $1000 \mathrm{~km}^{2}$.

Figure 8(b) shows that the CE densities were higher in the southern regions than in the northern regions. This is also shown in Table I which provides the climatological CE densities for the southern (northern) Vosges Mountains: 4.2 (3.8) enhancements per $1000 \mathrm{~km}^{2} \mathrm{y}^{-1}$; southern (northern) Rhine Valley: 6.5 (3.6) enhancements per $1000 \mathrm{~km}^{2} \mathrm{y}^{-1}$; southern (northern) Black Forest Mountains: 6.3 (3.3) enhancements per $1000 \mathrm{~km}^{2} \mathrm{y}^{-1}$ and western (eastern) Swabian Mountains: 6.2 (3.5) enhancements per $1000 \mathrm{~km}^{2} \mathrm{y}^{-1}$. It is unknown why the Vosges Mountain north-south climatological variability was much less than the other regional north-south variations. This higher density of CE events in the southern regions was also apparent in 2007 (Figure 8(b)). It is interesting but unclear why there is a distinct southern preference for CE events. The southern regions tend to have higher terrain than the northern regions, but this southern preference in convection was not observed as uniformly for CI events (Figure 8(a)).

\subsection{Diurnal evolution of convection}

Analyses above indicate that the daily variation in CI events during the COPS summer was significantly different from that found in the 8-year climatology. In this section, the diurnal cycles of CI and CE are examined. Figure 9 shows the climatological and COPS diurnal variation of the frequency of occurrence of CI and CE events. These data have been binned using a $30 \mathrm{~min}$ interval. While the autocorrelation analysis indicated that the e-folding parameter varied from 15 to $180 \mathrm{~min}$, the $30 \mathrm{~min}$ bin size was chosen to allow for an adequate sample size to more reliably calculate the variance (and thus the 95\% confidence interval) for each bin. Additionally $30 \mathrm{~min}$ is the minimum life time of a convective cell.

A peak in the frequency of CI events is evident between 1000 and 1200 UTC in both the climatology and the COPS summer (Figure 9(a)). An evaluation of the full $95 \%$ confidence interval (only the upper limit of the 95\% confidence interval is shown in Figure 9) indicates that this peak in the climatology is significant with a confidence of up to $95 \%$. The frequency of CI events is clearly related to the diurnal cycle (local noon is at 1130 UTC), suggesting a strong relationship of the CI events to surface heating and subsequent destabilization of the lower atmosphere. The rapid increase in CI events until solar noon is followed by a gradual decrease in CI events throughout the afternoon, resulting in the positively skewed appearance to the distributions. This period of gradually decreasing CI occurs during the time of day when secondary CI associated with outflow boundaries is likely to be occurring. Table I shows that the daytime (0500-1700 UTC) CI densities averaged $7.7 \mathrm{CI}$ events per $1000 \mathrm{~km}^{2} \mathrm{y}^{-1}$ while the nighttime (1700-0500 UTC) CI densities averaged 2.6 CI events per $1000 \mathrm{~km}^{2} \mathrm{y}^{-1}$. The ratio of daytime to nighttime CI events was 3.0. More CI events occurred from midday through the afternoon and early evening hours rather than during the night, providing further evidence that local forcing associated with diurnal heating and upslope flow were important for CI events.

To assess whether the COPS period was similar to climatology, the non-parametric Wilcoxon-Mann-Whitney test was performed. This test indicated that the two distributions
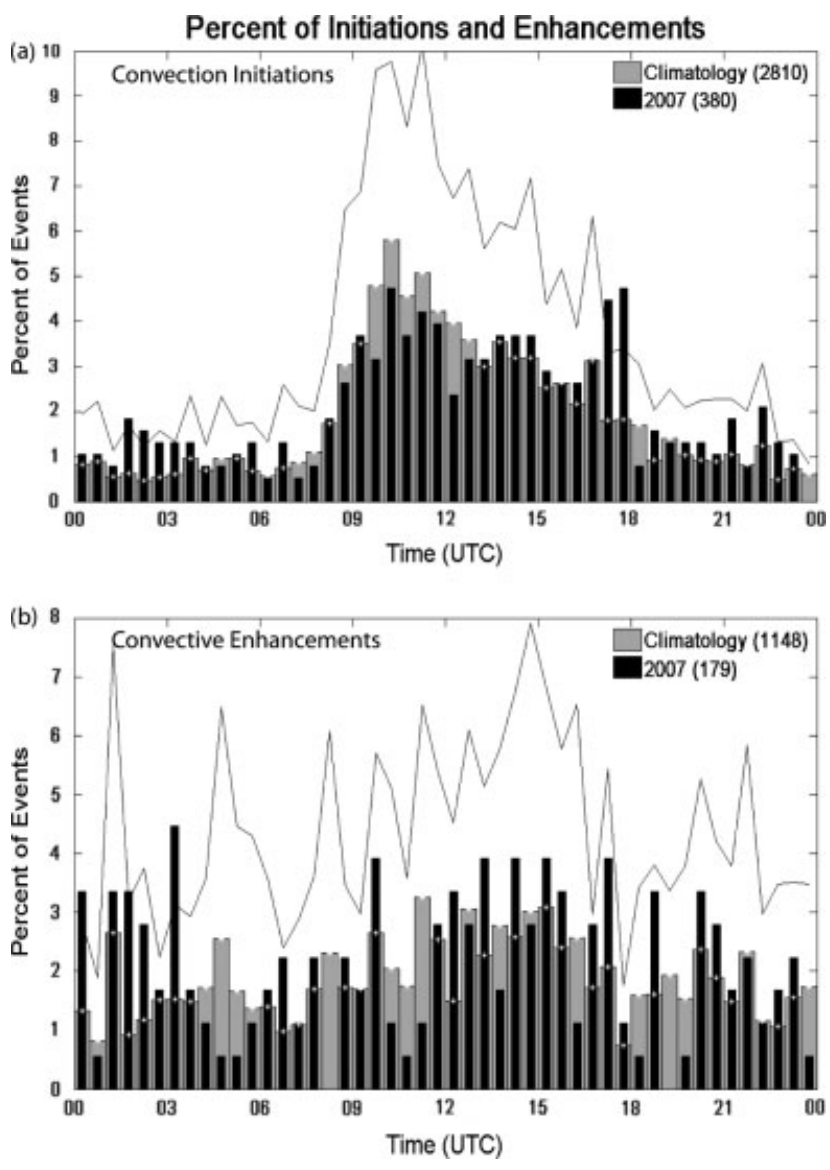

Figure 9. Percentage of (a) CI and (b) CE events versus time of day (UTC) in 2000-2006 and 2008 (grey bars) and the COPS summer (black bars). Histogram bars are 30 min intervals. The climatological mean values are shown as white crosses and the grey line denotes the high side of the $95 \%$ confidence interval.

were drawn from different populations at the $99.9 \%$ confidence interval. In contrast to the climatology, the COPS data exhibit a broad daytime maximum in CI with a secondary peak occurring between 1700 and 1800 UTC. This peak was not caused by a large system on just a few days but was due to numerous CI events occurring on 18 COPS days. Note that the CI percentage observed at 1700-1800 UTC during COPS differed from climatology at the $95 \%$ confidence level. Another difference is that nighttime CI events during COPS were more frequent than climatology with most nighttime COPS CI bins exceeding the climatological mean and many bins nearing the upper $95 \%$ confidence interval. This is quantified further by the ratio of daytime ( 6.7 events per $\left.1000 \mathrm{~km}^{2}\right)$ to night-time (3.9 events per $\left.1000 \mathrm{~km}^{2}\right) \mathrm{CI}$ events observed during COPS (1.7) being different from the climatological day/night ratio (3.0). The differences in the day/night ratio of CI events during COPS further suggests that the COPS summer exhibited less diurnal, local forcing and that the COPS CI events were influenced more by synoptic-scale forcing.

The COPS CI peak of 1000-1200 UTC occurs earlier than the previous COPS CI study of Aoshima et al. (2008), who found a maximum of satellite-observed CI at 1300-1400 UTC. They used only a COPS subset of Intensive Operation Period (IOP) days. When these radar CI data were similarly reduced to IOP days only and compared with the Aoshima et al. (2008) distribution, the nonparametric Wilcoxon-Mann-Whitney test resulted in a 
Table I. Annual summertime average density of convective events (events per $1000 \mathrm{~km}^{2} \mathrm{y}^{-1}$ ) for various regions of Figure 1 during 2000 to 2006 and 2008. The COPS summer densities are shown in parentheses. CI is all convection initiation events and CE is for all of the convective enhancement events. The CI events are separated according to maximum reflectivity, size, duration of the storm and time of initiation. 'Avg mtns' is the average density of all mountain regions (i.e. south and north Vosges, south and north Black Forest, west and east Swabian). 'Avg valleys' is the average density in the south Rhine and north Rhine Valleys

\begin{tabular}{|c|c|c|c|c|c|c|c|c|c|c|c|c|c|c|}
\hline \multirow[t]{2}{*}{ Region } & \multirow[t]{2}{*}{$\mathrm{CI}$} & \multirow[t]{2}{*}{$\mathrm{CE}$} & \multicolumn{4}{|c|}{ Maximum reflectivity (dBZ) } & \multicolumn{3}{|c|}{ Size $\left(100 \mathrm{~km}^{2}\right)$} & \multicolumn{3}{|c|}{ Duration $(\mathrm{h})$} & \multicolumn{2}{|c|}{ Time (UTC) } \\
\hline & & & 36 & 45 & 54 & $>55$ & $<20$ & $20-35$ & $>35$ & 1 & 2 & $>3$ & $\begin{array}{c}0500- \\
1700\end{array}$ & $\begin{array}{c}1700- \\
0500\end{array}$ \\
\hline $\mathrm{V}$ & $\begin{array}{c}12.6 \\
(12.5)\end{array}$ & $\begin{array}{c}4.2 \\
(8.3)\end{array}$ & $\begin{array}{c}0.8 \\
(1.9)\end{array}$ & $\begin{array}{c}3.1 \\
(2.8)\end{array}$ & $\begin{array}{c}5.4 \\
(3.7)\end{array}$ & $\begin{array}{c}3.4 \\
(4.2)\end{array}$ & $\begin{array}{c}6.3 \\
(5.1)\end{array}$ & $\begin{array}{c}3.8 \\
(4.2)\end{array}$ & $\begin{array}{c}2.6 \\
(3.2)\end{array}$ & $\begin{array}{c}2.1 \\
(1.9)\end{array}$ & $\begin{array}{c}2.4 \\
(1.9)\end{array}$ & $\begin{array}{c}8.1 \\
(8.8)\end{array}$ & $\begin{array}{c}9.7 \\
(7.9)\end{array}$ & $\begin{array}{c}2.9 \\
(4.6)\end{array}$ \\
\hline N. Vosges & $\begin{array}{c}13.7 \\
(13.8)\end{array}$ & $\begin{array}{c}3.8 \\
(4.6)\end{array}$ & $\begin{array}{c}1.2 \\
(2.3)\end{array}$ & $\begin{array}{c}4.1 \\
(3.1)\end{array}$ & $\begin{array}{c}5.7 \\
(6.2)\end{array}$ & $\begin{array}{c}2.7 \\
(2.3)\end{array}$ & $\begin{array}{c}7.6 \\
(7.7)\end{array}$ & $\begin{array}{c}3.2 \\
(1.5)\end{array}$ & $\begin{array}{c}2.9 \\
(4.6)\end{array}$ & $\begin{array}{c}2.4 \\
(1.5)\end{array}$ & $\begin{array}{c}3.7 \\
(3.8)\end{array}$ & $\begin{array}{c}7.5 \\
(8.5)\end{array}$ & $\begin{array}{l}11.4 \\
(7.7)\end{array}$ & $\begin{array}{c}2.2 \\
(6.2)\end{array}$ \\
\hline S. Rhine Valley & $\begin{array}{c}7.4 \\
(7.3)\end{array}$ & $\begin{array}{c}6.5 \\
(7.1)\end{array}$ & $\begin{array}{c}1.2 \\
(0.9)\end{array}$ & $\begin{array}{c}1.9 \\
(1.3)\end{array}$ & $\begin{array}{c}3.0 \\
(3.4)\end{array}$ & $\begin{array}{c}1.5 \\
(1.7)\end{array}$ & $\begin{array}{c}4.5 \\
(4.1)\end{array}$ & $\begin{array}{c}1.7 \\
(1.7)\end{array}$ & $\begin{array}{c}1.3 \\
(1.5)\end{array}$ & $\begin{array}{c}1.7 \\
(0.9)\end{array}$ & $\begin{array}{c}2.1 \\
(2.6)\end{array}$ & $\begin{array}{c}3.6 \\
(3.9)\end{array}$ & $\begin{array}{c}4.6 \\
(3.9)\end{array}$ & $\begin{array}{c}2.8 \\
(3.5)\end{array}$ \\
\hline N. Rhine & $\begin{array}{c}6.3 \\
(9.9)\end{array}$ & $\begin{array}{c}3.6 \\
(4.5)\end{array}$ & $\begin{array}{c}1.0 \\
(2.1)\end{array}$ & $\begin{array}{c}2.3 \\
(3.2)\end{array}$ & $\begin{array}{c}2.3 \\
(3.7)\end{array}$ & $\begin{array}{c}0.7 \\
(0.9)\end{array}$ & $\begin{array}{c}4.3 \\
(6.6)\end{array}$ & $\begin{array}{c}1.1 \\
(2.0)\end{array}$ & $\begin{array}{c}0.9 \\
(1.3)\end{array}$ & $\begin{array}{c}1.8 \\
(2.6)\end{array}$ & $\begin{array}{c}1.9 \\
(2.6)\end{array}$ & $\begin{array}{c}2.6 \\
(4.6)\end{array}$ & $\begin{array}{c}4.1 \\
(5.6)\end{array}$ & $\begin{array}{c}2.2 \\
(4.4)\end{array}$ \\
\hline S. Black Forest & $\begin{array}{c}14.6 \\
(13.0)\end{array}$ & $\begin{array}{c}6.3 \\
(7.2)\end{array}$ & $\begin{array}{c}0.7 \\
(0.6)\end{array}$ & $\begin{array}{c}2.7 \\
(2.9)\end{array}$ & $\begin{array}{c}6.0 \\
(4.9)\end{array}$ & $\begin{array}{c}5.1 \\
(4.6)\end{array}$ & $\begin{array}{c}7.8 \\
(5.8)\end{array}$ & $\begin{array}{c}3.4 \\
(4.3)\end{array}$ & $\begin{array}{c}3.4 \\
(2.9)\end{array}$ & $\begin{array}{c}2.6 \\
(2.0)\end{array}$ & $\begin{array}{c}3.3 \\
(3.2)\end{array}$ & $\begin{array}{c}8.7 \\
(7.8)\end{array}$ & $\begin{array}{l}11.4 \\
(9.3)\end{array}$ & $\begin{array}{c}3.1 \\
(3.8)\end{array}$ \\
\hline N. Black Forest & $\begin{array}{c}12.2 \\
(13.1)\end{array}$ & $\begin{array}{c}3.3 \\
(2.7)\end{array}$ & $\begin{array}{c}1.2 \\
(2.3)\end{array}$ & $\begin{array}{c}3.5 \\
(0.9)\end{array}$ & $\begin{array}{c}4.8 \\
(6.8)\end{array}$ & $\begin{array}{c}2.7 \\
(3.2)\end{array}$ & $\begin{array}{c}7.2 \\
(7.2)\end{array}$ & $\begin{array}{c}2.4 \\
(2.7)\end{array}$ & $\begin{array}{c}2.6 \\
(3.2)\end{array}$ & $\begin{array}{c}2.3 \\
(2.3)\end{array}$ & $\begin{array}{c}3.6 \\
(3.6)\end{array}$ & $\begin{array}{c}6.3 \\
(7.2)\end{array}$ & $\begin{array}{c}9.6 \\
(7.7)\end{array}$ & $\begin{array}{c}2.6 \\
(5.4)\end{array}$ \\
\hline W. Sw & $\begin{array}{c}16.0 \\
(12.7)\end{array}$ & $\begin{array}{c}6.2 \\
(8.1)\end{array}$ & $\begin{array}{c}1.8 \\
(0.9)\end{array}$ & $\begin{array}{c}3.6 \\
(4.5)\end{array}$ & $\begin{array}{c}6.5 \\
(5.0)\end{array}$ & $\begin{array}{c}4.2 \\
(2.3)\end{array}$ & $\begin{array}{c}8.9 \\
(7.2)\end{array}$ & $\begin{array}{c}3.8 \\
(2.7)\end{array}$ & $\begin{array}{c}3.3 \\
(2.7)\end{array}$ & $\begin{array}{c}2.6 \\
(3.2)\end{array}$ & $\begin{array}{c}4.7 \\
(0.9)\end{array}$ & $\begin{array}{c}8.7 \\
(8.6)\end{array}$ & $\begin{array}{l}13.3 \\
(9.5)\end{array}$ & $\begin{array}{c}2.8 \\
(3.2)\end{array}$ \\
\hline E. Swabian & $\begin{array}{c}12.0 \\
(13.8)\end{array}$ & $\begin{array}{c}3.5 \\
(6.7)\end{array}$ & $\begin{array}{c}1.1 \\
(0.5)\end{array}$ & $\begin{array}{c}3.0 \\
(1.4)\end{array}$ & $\begin{array}{c}5.7 \\
(10.0)\end{array}$ & $\begin{array}{c}2.1 \\
(1.9)\end{array}$ & $\begin{array}{c}7.5 \\
(9.0)\end{array}$ & $\begin{array}{c}2.7 \\
(3.8)\end{array}$ & $\begin{array}{c}2.0 \\
(1.0)\end{array}$ & $\begin{array}{c}3.5 \\
(2.4)\end{array}$ & $\begin{array}{c}2.9 \\
(4.8)\end{array}$ & $\begin{array}{c}5.7 \\
(6.7)\end{array}$ & $\begin{array}{c}10.1 \\
(10.0)\end{array}$ & $\begin{array}{c}1.9 \\
(3.8)\end{array}$ \\
\hline Avg mtns & $\begin{array}{c}13.5 \\
(13.2)\end{array}$ & $\begin{array}{c}4.6 \\
(6.3)\end{array}$ & $\begin{array}{c}1.1 \\
(1.4)\end{array}$ & $\begin{array}{c}3.3 \\
(2.6)\end{array}$ & $\begin{array}{c}5.7 \\
(6.1)\end{array}$ & $\begin{array}{c}3.4 \\
(3.1)\end{array}$ & $\begin{array}{c}7.6 \\
(7.0)\end{array}$ & $\begin{array}{c}3.2 \\
(3.2)\end{array}$ & $\begin{array}{c}2.8 \\
(2.9)\end{array}$ & $\begin{array}{c}2.6 \\
(2.2)\end{array}$ & $\begin{array}{c}3.4 \\
(3.0)\end{array}$ & $\begin{array}{c}7.5 \\
(7.9)\end{array}$ & $\begin{array}{l}10.9 \\
(8.7)\end{array}$ & $\begin{array}{c}2.6 \\
(3.9)\end{array}$ \\
\hline Avg valleys & $\begin{array}{c}6.9 \\
(8.6)\end{array}$ & $\begin{array}{c}5.1 \\
(5.8)\end{array}$ & $\begin{array}{c}1.1 \\
(1.5)\end{array}$ & $\begin{array}{c}2.1 \\
(2.3)\end{array}$ & $\begin{array}{c}2.7 \\
(3.6)\end{array}$ & $\begin{array}{c}1.1 \\
(1.3)\end{array}$ & $\begin{array}{c}4.4 \\
(5.4)\end{array}$ & $\begin{array}{c}1.4 \\
(1.9)\end{array}$ & $\begin{array}{c}1.1 \\
(1.4)\end{array}$ & $\begin{array}{c}1.8 \\
(1.8)\end{array}$ & $\begin{array}{c}2.0 \\
(2.6)\end{array}$ & $\begin{array}{c}3.1 \\
(4.3)\end{array}$ & $\begin{array}{c}4.4 \\
(4.7)\end{array}$ & $\begin{array}{c}2.5 \\
(3.9)\end{array}$ \\
\hline
\end{tabular}

79.2\% confidence level that the distributions are similar. The differences in the peak CI occurrences may be explained by the different datasets used because radar identifies CI events before IR brightness temperatures show substantial cloud-top cooling.

The climatological diurnal cycle of $\mathrm{CE}$ events has a small amplitude increase during the day (1100-1700 UTC) while the COPS diurnal cycle has a great deal of variability with no clear relationship between CEs and time of day (Figure 9(b)). According to the non-parametric Wilcoxon-Mann-Whitney test, the climatological CE and COPS CE distributions of Figure 9(b) were distinct with a confidence of $99.0 \%$, indicating that CE during the COPS summer was unique (i.e. not drawn from the same population as climatology). Table I shows that the density of daytime CE events (2.8 enhancement events per $\left.1000 \mathrm{~km}^{2} \mathrm{y}^{-1}\right)$ was slightly greater than night-time CE events (1.9 enhancement events per $1000 \mathrm{~km}^{2} \mathrm{y}^{-1}$ ) with a daytime to night-time ratio of 1.5. During COPS, the density of daytime CE events (3.1 enhancement events per $1000 \mathrm{~km}^{2} \mathrm{y}^{-1}$ ) was similar to that of nighttime CE events (2.8 enhancement events per $1000 \mathrm{~km}^{2} \mathrm{y}^{-1}$ ) with a daytime to nighttime ratio of 1.1, again suggesting less impact of local heating effects during the COPS summer than in the climatology.

Further analyses have been performed to assess how the CI events varied regionally across the COPS domain. This was done by dividing the number of events for each region (defined in Figure 1) by the area of the region to calculate the CI density. The CI density calculated for each region using the entire 2000-2008 period was then plotted as a function of time of day (Figure 10(a)). While there is no clear variation in timing of maximum CI density for the various mountain regions of the COPS domain, there is some variation in the magnitude of the peaks for each region. The most notable feature is the difference in the amplitude of the diurnal variation found between the mountains and the Rhine Valley. These differences indicate that mountain $\mathrm{CI}$ is strongly influenced by daytime heating, while CI in the Rhine Valley is not.

Given these regional differences in the timing of CI, the regional variation in the relationship between $\mathrm{CI}$ and the occurrence of strong storms is assessed by plotting the diurnal cycle of the frequency of occurrence of thunderstorms with reflectivities $>46 \mathrm{dBZ}$ for each region (Figure $10(\mathrm{~b}))$. It is noted that roughly $62 \%$ of the CI events shown in Figure 10(a) contribute to the diurnal cycle of strong storms shown in Figure 10b. The remainder of strong storms shown in Figure 10(b) propagated into the domain. It is seen that the peak in strong storms occurs $\sim 2 \mathrm{~h}$ after the peak in CI events (Figure 10). It is also seen that the peak occurrence of strong storms occurs first over the mountains and then, about two hours later, in the Rhine Valley (Figure 10(b)). This $2 \mathrm{~h}$ lag may be explained by the propagation of storms off the Vosges Mountains and into the Rhine Valley. Additionally, it is possible that the 

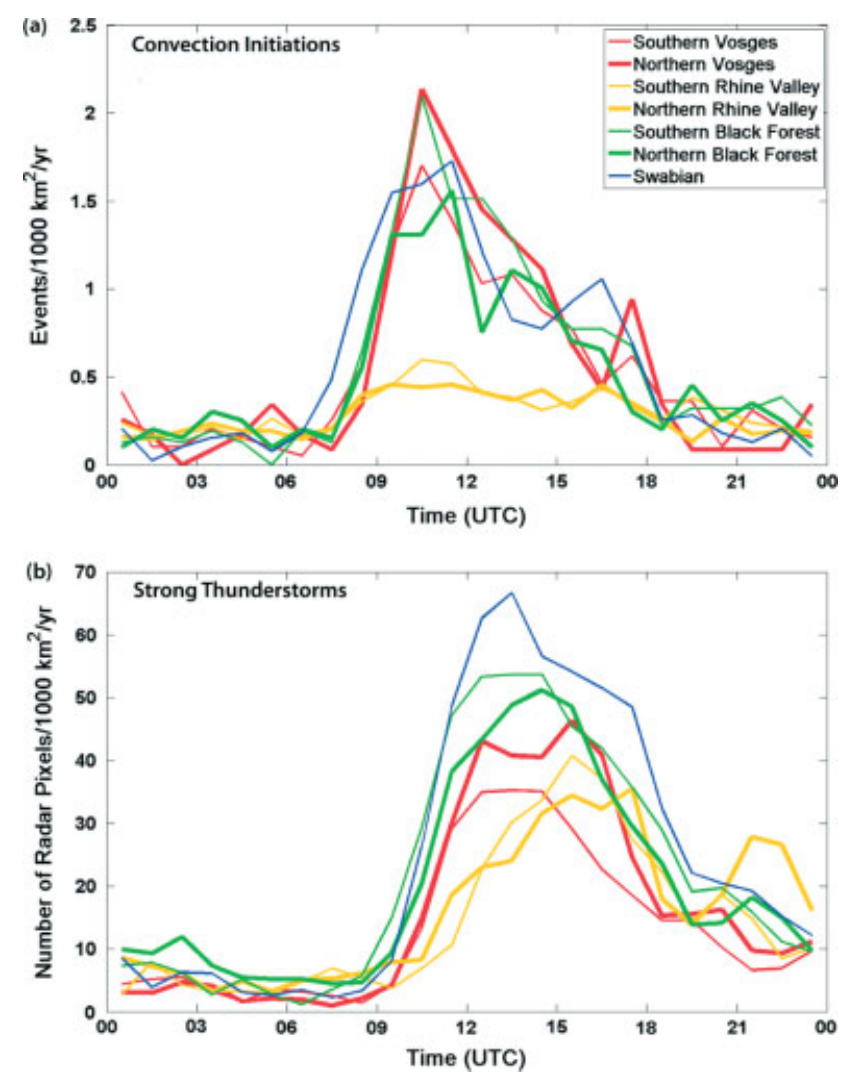

Figure 10. Timing of (a) CI densities and (b) strong thunderstorm densities (with reflectivities $>46 \mathrm{dBZ}$ ) for the different regions illustrated in Figure 1.

storms propagated over the Vosges Mountains and then first decayed before they intensified again over the Rhine Valley.

\section{Conclusions}

Results of a nine-year European radar data climatology from the COPS region of southwestern Germany and eastern France are presented from the summer months (May-August) of 2000-2008. While this study utilizes accepted methodologies in identifying and evaluating CI events using radar reflectivity data (e.g. Wilson and Schreiber, 1986; Wilson and Roberts, 2006), it should be noted that different data and/or different methodologies may produce somewhat different climatological results. It is believed, however, that the main points herein are robust and would withstand variations in applied methodologies. The DWD and MeteoSwiss composite radar data show numerous CI and CE events in the low-mountain regions of the COPS domain. Storms were initiated and enhanced throughout the region, including in the Rhine Valley. The climatological frequency of storms in the region was high, with more than $61 \%(42 \%)$ of the summertime days having CI (CE) events. During the COPS summer, 71\% (52\%) of the summertime days had CI (CE) events.

The CI densities of the climatology showed preferred development locations which could be useful for forecasting applications: the CI density in the mountain regions for the full climatology was twice the CI density in the Rhine Valley. The COPS CI density ratio for the mountains and valleys was 1.5. The CE densities observed for the climatology and COPS summer did not exhibit a clear relationship to the topography: the mountain to valley ratio of CE densities for both the climatology and COPS was 0.9-1.1. A preference of
CE events in the southern regions of the various mountain ranges and Rhine Valley, however, was observed.

The eight-year climatological CI frequency produced a mid-day (1000-1200 UTC) peak, suggesting a strong relationship with diurnal heating and associated upslope flows and convergence lines produced by differential heating. In fact, the radar climatology showed that there were 3.0 times as many $\mathrm{CI}$ events during the day than during the night. The ratio of day to night-time storms during COPS (1.7) was less than climatology. While the CE events did not exhibit a clear diurnal peak, there was a slight increase in the number of daytime events. The ratio of daytime to night-time CE events was 1.5 for the climatology and 1.1 for the COPS summer. Both the mountain/valley comparisons and the diurnal variation results support the suggestion of stronger synoptic-scale forcing influencing the CI events during the COPS summer than the dominant local forcing in the climatology.

When the CI events were stratified by intensity, size and duration, it was apparent that the strongest, largest and long-lived storms initiated most frequently in the mountains (mountain to Rhine Valley ratio of 2-3) while the weaker, smaller and short-lived storms were more evenly distributed between the mountains and Rhine Valley (mountain to Rhine Valley ratio of 1.5). While CI peaked at 1000-1200 UTC, the stronger thunderstorms appeared first in the mountains at 1200-1400 UTC and later in the Rhine Valley (1500-1700 UTC).

Even though the mountain CI and CE densities were higher than the Rhine Valley, it was interesting to observe the high frequency of events in the Rhine Valley. One possible reason for $\mathrm{CI}$ in the Rhine Valley may be the common occurrence of boundary-layer convergence zones. Hagen et al. (2011) frequently observed CI in the Rhine Valley on days with strong southwesterly winds. They attributed the origin of CI to convergence zones caused by flow around the Vosges at the southern and northern ends and flow through the west-east oriented gaps and valleys of the Vosges. Low-level convergence zones were also shown to be important for CI in the COPS region by Kottmeier et al. (2008). Such boundary-layer convergence zones were often observed by the Doppler on Wheels (DOWs; Wurman et al., 1997) mobile radars, typically positioned in the Rhine Valley during COPS. Some of those boundaries occurred at distinct angles to the mountains and valleys. Thus the causes of the boundaries could be slope flows, valley flows and channelling and blockage by the various mountain ranges. Such boundaries and their relationships with convection will be analyzed in future studies with a combination of DOW data, extensive and diverse COPS datasets, and numerical modelling studies.

\section{Acknowledgements}

The German Weather Service (DWD) is gratefully acknowledged for providing the physical initialization (PI) radar data used for this study. Katja Friedrich (University of Colorado) provided two summers of MeteoSwiss radar data used to fill in the gaps in the DWD data. Niles Oien (NCAR/Research Applications Laboratory, RAL) was critical for translating the data and setting up the European Configurable Interactive Data Display for analysis at NCAR. Janine Goldstein (NCAR/Earth Observing Laboratory, EOL), Jean Hurst (NCAR/EOL) and 
Bruce Morley (NCAR/EOL) assisted in various parts of the convection initiation identifications. Wiebke Deierling (NCAR/RAL) provided a thorough, constructive review of an earlier version of this manuscript. Statistics discussions with Kate Young were greatly appreciated. Two anonymous reviewers are acknowledged for providing helpful comments that substantially improved the manuscript. The NCAR Short-Term Explicit Prediction (STEP) program is gratefully acknowledged for supporting a portion of this research. The National Center for Atmospheric Research (NCAR) is sponsored by the National Science Foundation.

\section{References}

Aoshima F, Behrendt A, Bauer H-S, Wulfmeyer V. 2008. Statistics of convection initiation by use of Meteosat rapid scan data during the Convective and Orographically-induced Precipitation Study (COPS). Meteorol. Zeit. 17: 921-930. DOI: 10.1127/0941-2948/2008/0337.

Banta RM, SchaafCB. 1987. Thunderstorm genesis zones in the Colorado Rocky Mountains as determined by traceback of geosynchronous satellite images. Mon. Weather Rev. 115: 463-476.

Finke U, Hauf T. 1996. The characteristics of lightning occurrence in southern Germany. Contrib. Atmos. Phys. 69: 361-374.

Grebe L. 2009. 'Klimatologie von Gewittern im Gebiet der COPS Messkampgne'. Diploma thesis, Ludwig Maximilians Universität München, Germany. Available from http://elib.dlr.de/62184/.

Hagen M, Bartenschlager B, Finde U. 1999. Motion characteristics of thunderstorms in southern Germany. Meteorol. Appl. 6: 227-239.

Hagen M, van Baelen J, Richard E. 2011. Influence of the wind profile on the location of hotspots of convection in mountainous terrain. $Q$. J. R. Meteorol. Soc. 137(S1): 224-235, DOI: 10.1002/qj.784.

Höller H. 1994. Mesoscale organization and hailfall characteristics of deep convection in southern Germany. Beitr. Phys. Atmos. 67: 219-234.

Kalthoff N, Adler B, Barthlott C, Corsmeier U, Mobbs S, Crewell S, Träumner K, Kottmeier C, Wieser A, Smith V, Di Girolamo P. 2009. The impact of convergence zones on the initiation of deep convection: A case study from COPS. Atmos. Res. 93: 680-694.

Kalthoff N, Kohler M, Barthlott C, Mobbs D, Corsmeier U, Träumner K, Foken T, Eigenmann R, Krauss L, Khodayar S, Di Girolamo P. 2011 The dependence of convection-related parameters on surface and boundary-layer conditions over complex terrain. Q. J. R. Meteorol. Soc. 137(S1): 71-81, DOI: 10.1002/qj.686.

Kottmeier C, Kalthoff N, Barthlott C, Corsmeier U, van Baelen J, Behrendt A, Behrendt R, Blyth A, Coulter R, Crewell S, DiGirolamo P, Dorninger M, Flamant C, Foken T, Hagen M, Hauck C, Höller H, Konow H, Kunz M, Mahlke H, Mobbs S, Richard E, Steinaker R, Weckwerth T, Wieser A, Wulfmeyer V. 2008. Mechanisms initiating deep convection over complex terrain during COPS. Meteorol. Z. 17: 931-948.

Mecikalski JR, Bedka KM. 2006. Forecasting convective initiation by monitoring the evolution of moving cumulus in daytime GOES imagery. Mon. Weather Rev. 134: 49-78.

Mercer AE, Richman MB. 2007. Statistical differences of quasigeostrophic variables, stability, and moisture profiles in North American storm tracks. Mon. Weather Rev. 135: 2312-2338.

Rife DL, Davis CA, Knievel JC. 2009. Temporal changes in wind as objects for evaluating mesoscale numerical weather prediction. Weather Forecasting 24: 1374-1389, DOI: 10.1175/2009WAF2222223.1.

Roberts RD, Rutledge S. 2003. Nowcasting storm initiation and growth using GOES-8 and WSR-88D data. Weather Forecasting 18: 562-584.

Tucker DF, Crook NA. 2005. Flow over heated terrain. Part II: Generation of convective precipitation. Mon. Weather Rev. 133: 2565-2582.

Wilks DS. 2006. Statistical Methods in the Atmospheric Sciences. Internat. Geophys. Series 91: Academic Press: Oxford, UK.

Wilson JW, Roberts RD. 2006. Summary of convective storm initiation and evolution during IHOP: Observational and modeling perspective. Mon. Weather Rev. 134: 23-47.

Wilson JW, Schreiber WE. 1986. Initiation of convective storms by radar-observed boundary layer convergent lines. Mon. Weather Rev. 114: $2516-2536$.

Wulfmeyer V, Behrendt A, Bauer H-S, Kottmeier C, Corsmeier U, Blyth A, Craig G, Schumann U, Hagen M, Crewell S, DiGirolamo P, Flamant C, Miller M, Montani A, Mobbs S, Richard E, Rotach MW, Arpagaus M, Russchenberg H, Schluessel P, Koenig M, Gaertner V, Steinacker R, Dorninger M, Turner DD, Weckwerth T. 2008. The Convective and Orographically induced Precipitation Study: A research and development project of the world weather research program for improving quantitative precipitation forecasting in lowmountain regions. Bull. Amer. Meteorol. Soc. 89: 1477-1486, DOI 10.1175/2008BAMS2367.1.

Wulfmeyer V, Behrendt A, Kottmeier C, Corsmeier U, Barthlott C, Craig GC, Hagen M, Althausen D, Aoshima F, Arpagaus M, Bauer HS, Bennett L, Blyth A, Brandau C, Champollion C, Crewell S, Dick G, Di Girolamo P, Dorninger M, Dufournet Y, Eigenmann R, Flamant C, Foken T, Gorgas T, Grzeschik M, Handwerker J, Hauck C, Höller H, Junkermann W, Kalthoff N, Kiemle C, Klink S, König M, Krauss L, Long CN, Madonna F, Mobbs S, Neininger B, Pal S, Peters G, Pigeon G, Richard E, Rotach MW, Russchenberg H, Schwitalla T, Smith V, Steinacker R, Trentmann J, Turner DD, van Baelen J, Vogt S, Volkert H, Weckwerth T, Wernli H, Wieser A, Wirth M. 2011. The Convective and Orographically-induced Precipitation Study (COPS): The scientific strategy, the field phase and research highlights. Q. J. R. Meteorol. Soc. 137(S1): 3-30, DOI: 10.1002/qj.752.

Wurman J, Straka J, Rasmussen E, Randall M, Zahrai A. 1997. Design and deployment of a portable, pencil-beam, pulsed, $3 \mathrm{~cm}$ Doppler radar. J. Atmos. Oceanic Technol. 14: 1502-1512.

Yue S, Wang C. 2002. The influence of serial correlation on the Mann-Whitney test for detecting a shift in median. Adv. Water Res. 25: 325-333. 